\title{
Characterization of Chemical Constituent and Antibacterial Activity of Honje Fruit Skin (Etlingera elatior)
}

\author{
Dede Sukandar $^{\text {a }}$, Fitriyanti ${ }^{\text {b* }}$, Eka Rizki Amelia ${ }^{c}$, Adi Riyadhi ${ }^{\text {d }}$ and Ramma Nur Azizah ${ }^{\mathrm{e}}$ \\ ${ }^{a, b, b, c, d, e}$ Department of Chemistry, \\ Syarif Hidayatullah State Islamic University \\ Jl. Ir. H. Juanda No 95 Ciputat 15412 \\ *Email : fitriyanti@uinjkt.ac.id
}

\begin{abstract}
Characteristic of chemical constituent and antibacterial property from Etlingera elatior fruit have been carried out. Essential oil of plant was extracted using steam and water distillation and then analyzed by gas chromatography-mass spectrometry. Antibacterial activity of the essential oil was done through disc diffusion method against Bacillus cereus, Staphylococcus aureus, Eschericia coli and Pseudomonas aeruginosa. Percentage yield of essential oil was about $0,09 \%(\mathrm{v} / \mathrm{w})$. The GC-MS profile revealed that E. elatior contained 35 compounds where 1-dodecanol, dodecanal and trans-caryophyllene were predicted to be main components. The oil showed activity against $B$. Cereus, S. Aureus, E. Coli, and P. aeruginosa with zone of inhibition were about 25, 15.2, 11.67 and $12.33 \mathrm{~mm}$ respectively.
\end{abstract}

Keywords: Essential oil, Etlingera elatior, Gas chromatography-mass spectroscopy, Antibacterial activity

\section{Introduction}

Food generally has a relatively short shelf life where it is easily damaged (perishable). Water content in the food is the main factors to decide the shelf life of food. The higher water content of food, the greater damage of likelihood will occur, where it is as a result of internal biological activity (metabolism) and the entry of destructive microbes [1].

Most of instant foods use preservative to prevent the growing of microbial [2]. The use of synthetic food preservative has been known to have many disadvantages which cause side effects to human's body. To cope this solution, natural food preservatives have been developed which is less side effects. One of the types of compounds that can be used as a natural food preservative is a natural antimicrobial compounds [3]. Natural antimicrobial can be used as a natural food preservative which is required to replace chemical preservatives that have a risk to health such as food-borne illness. In order to reduce the number of cases of food-borne illness, applying antimicrobials into food processing is an alternative to inactivate or prevent the growth of microbial [4]. Natural food preservative containing antimicrobial substances may be derived from natural plants. Essential oil has been known to have antimicrobial property which benefits as food preservative. Etlingera elatior (Figure 1) is family of Zingiberaceae and commonly distributed in West Java and Banten. E. elatior has been traditionally used as a spice for cooking and odor remover [5].

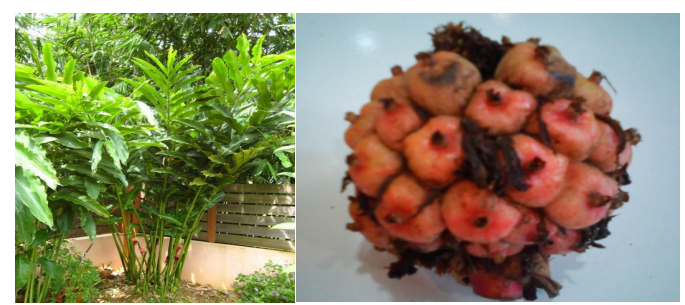

Figure 1. Plant and Fruit of Honje

Previous studies on bioactivity of E. elatior were reported. Ethanol extract of the leaves of E. elatior showed activity against bacteria gram-positive (Bacillus cereus and Bacillus megatrium) and bacteria gram negative (Escherichia coli and Pseudomonas aeruginosa). The results revealed that $E$. elatior showed antibacterial activity with minimum concentration $100-800 \mathrm{mg} / \mathrm{mL}$ and the minimum lethal concentration $400-800 \mathrm{mg} / \mathrm{mL}$ [6]. In addition, E. elatior had antibacterial activity against $S$. aureus with minimum inhibitory concentration values about $15 \%$ of concentrations at with the percentage of inhibition about $95.63 \%$, E. coli by $50 \%$ with the percent inhibition of $92.41 \%$. These concentrations were considered to be natural food preservative [7].

This study was aimed on characterization of chemical constituent from E. elatior using gas chromatographymass spectroscopy and screening for its antibacterial activity against pathogenic bacteria.

\section{Research Method}

\subsection{Plant material and extraction process}

Honje fruit (Etlingera elatior) was collected from Cintaratu Village, District Parigi, District of Pangandaran, 
West Java. The specimen of the plant was verified at Field Botany Biology Research Center Cibinong LIPI, Bogor.

About $2 \mathrm{~kg}$ of E. elatior was placed into steam-water distillation and extracted for $6 \mathrm{~h}$ to obtain essential oil. After extraction, excessive water in essential oil was removed by anhydrous sodium sulphate. The essential oil was stored at $4{ }^{\circ} \mathrm{C}$.

\subsection{Gas chromatography analysis}

Chemical constituent of essential oil from E. elantior was analyzed using gas chromatography-mass spectroscopy (GC-MS) technique. GC-MS analyzer was performed using Agilents Technologies 68890 N Network GC system, equipped with semi-polar column, type HP$5 \mathrm{MS}(30 \mathrm{~m} \times 0.25 \mathrm{~mm} \times 0.25 \mathrm{~mm})$. Helium was performed as carrier gas and around $0.1 \mu \mathrm{L}$ of essential oil was injected $(1: 100)$. Temperature was programmed from 80 ${ }^{\circ} \mathrm{C}$ to $250{ }^{\circ} \mathrm{C}$.

\subsection{Antibacterial test: Disc diffusion method}

Antibacterial test of E. elantior against two bacteria gram positive Bacillus cereus, Staphylococcus aureus and gram negative Eschericia coli, Pseudomonas aeruginosa was evaluated using disc diffusion method. Bacteria was prepared in nutrient broth and incubated at $37{ }^{\circ} \mathrm{C}$ to standardize approximately $10^{8}$ colony forming unit (CFU). About $0.1 \mathrm{ml}$ of bacteria was subjected onto nutrient agar and swabbed using cotton swab. Sample was prepared in 20, 40 60, 80 and 100\% of concentration (v/v) in DMSO. Around $10 \mu \mathrm{L}$ of each concentration was injected into 11 $\mathrm{mm}$ of blank disc and allowed to dry. The discs were placed to cultured agar and incubated at $37{ }^{\circ} \mathrm{C}$ for $24 \mathrm{~h}$. Chloramphenicol was used as positive control and solvent DMSO as negative control. Clear inhibition zone indicated as a presence of antibacterial property of E. elatior.

\section{Research Result}

\subsection{Characteristic of Essential Oil}

Essential oil of Etlingera elatior was produced about $15.5 \mathrm{~mL}(0.009 \%)$ of $16.8 \mathrm{~kg}$ of dry weight sample. Physical properties of E. elatior were compared with Indonesian National Standard (SNI) ginger oil (SNI 061312-1998) and International Standard Oil of Ginger (ISO 7355:1995) as shown in Table 1.

Table 1. Characteristic of the physical properties of fruit skin honje essential oil

\begin{tabular}{|c|c|c|c|c|}
\hline No & Characteristic & $\begin{array}{c}\text { E. elatior } \\
\text { Fruit } \\
\text { essential oil }\end{array}$ & $\begin{array}{c}\text { SNI 06- } \\
1312-1998\end{array}$ & $\begin{array}{c}\text { ISO } \\
7355: 1995\end{array}$ \\
\hline 1 & $\begin{array}{c}\text { Specific gravity } \\
(\mathrm{g} / \mathrm{mL}) \\
25^{\circ} \mathrm{C} / 25^{\circ} \mathrm{C}\end{array}$ & 0,8814 & $\begin{array}{c}0,8720- \\
0,8890\end{array}$ & $\begin{array}{c}0,870- \\
0,890\end{array}$ \\
\hline 2 & $\begin{array}{c}\text { Refractive index } \\
25^{\circ} \mathrm{C}\end{array}$ & 1,451 & $\begin{array}{c}1,4853- \\
1,4920\end{array}$ & $\begin{array}{c}1,480- \\
1,490\end{array}$ \\
\hline 3 & $\begin{array}{c}\text { Solubility in } \\
\text { alcohol } 90 \%\end{array}$ & $1: 1$ & - & $1: 4$ \\
\hline
\end{tabular}

observed in fruit plants. Based on GC analysis, there are five main components in the essential oil of E. elatior, 1dodecanol $(\mathrm{RT}=20.70 \mathrm{~min} ; 25.59 \%)$, dodecanol $(\mathrm{RT}=$ $19.05 \mathrm{~min} ; 18.11 \%)$, trans-cryophyllene $(\mathrm{RT}=19.94 \mathrm{~min}$; $12.22 \%)$, cyclododecane $(\mathrm{RT}=25.38 \mathrm{~min}, 6.47 \%)$ and dodecyl ester (RT= $23.72 \mathrm{~min}$; 5.99\%) (Library Wiley 7). Alpha pinene appeared as the first compound to come out with retention time $8.76 \mathrm{~min}(0.41 \%)$ and cyclotetradecane was the last compound with RT $29.72 \mathrm{~min}(0.16 \%)$. Several compounds were also detected such as alpha copaene (RT $18.62 \mathrm{~min}, 0.16 \%)$, 2-methoxy-4-(2-propenyl) $(\mathrm{RT}=21.88$ min, $0.15 \%)$, alpha farnesene $(\mathrm{RT}=21.46 \mathrm{~min}, 0.19)$, 2pentadecanone $(\mathrm{RT}=25.85 \mathrm{~min}, 0.17 \%)$ and cycloundecane ( RT $=20.30 \mathrm{~min}, 0.19 \%$ ). Chemical constituent of $E$. elatior with molecular weight, peak area and retention time was shown in Table 2.

Table 2. The chemical components of E. elatior fruit essential oil

\begin{tabular}{|c|c|c|c|c|c|}
\hline RT & Compound & $\begin{array}{l}\text { molecular } \\
\text { formula }\end{array}$ & MW & $\begin{array}{c}\% \text { Peak } \\
\text { Area }\end{array}$ & $\%$ Similarity \\
\hline 8.76 & Alpha pinene & $\mathrm{C}_{10} \mathrm{H}_{16}$ & 136 & 0.41 & 97 \\
\hline 13.85 & Decanal & $\mathrm{C}_{10} \mathrm{H}_{20} \mathrm{O}$ & 156 & 1.38 & 91 \\
\hline 15.06 & Geraniol & $\mathrm{C}_{10} \mathrm{H}_{18} \mathrm{O}$ & 154 & 1.06 & 94 \\
\hline 15.41 & 1-Decanol & $\mathrm{C}_{10} \mathrm{H}_{22} \mathrm{O}$ & 158 & 1.51 & 91 \\
\hline 15.99 & 2-Undecanone & $\mathrm{C}_{11} \mathrm{H}_{22} \mathrm{O}$ & 170 & 0.35 & 94 \\
\hline 16.36 & Undecanal & $\mathrm{C}_{11} \mathrm{H}_{22} \mathrm{O}$ & 170 & 0.7 & 91 \\
\hline 17.94 & $\begin{array}{l}\text { 2-methoxy-4-(2- } \\
\text { propenyl) phenol }\end{array}$ & $\mathrm{C}_{10} \mathrm{H}_{12} \mathrm{O}_{2}$ & 164 & 3.26 & 98 \\
\hline 18.21 & Geranyl acetate & $\mathrm{C}_{12} \mathrm{H}_{20} \mathrm{O}_{2}$ & 196 & 0.26 & 91 \\
\hline 18.62 & Alpha copaene & $\mathrm{C}_{15} \mathrm{H}_{24}$ & 204 & 0.16 & 99 \\
\hline 19.05 & Dodecanal & $\mathrm{C}_{12} \mathrm{H}_{24} \mathrm{O}$ & 184 & 18.11 & 91 \\
\hline 19.94 & $\begin{array}{l}\text { Trans } \\
\text { caryophyllene }\end{array}$ & $\mathrm{C}_{15} \mathrm{H}_{24}$ & 204 & 12.22 & 99 \\
\hline 20.15 & Beta bisabolene & $\mathrm{C}_{15} \mathrm{H}_{24}$ & 204 & 0.22 & 86 \\
\hline 20.30 & $\begin{array}{l}\text { Cycloundecene, } \\
\text { 1-methyl }\end{array}$ & $\mathrm{C}_{12} \mathrm{H}_{22}$ & 166 & 0.19 & 95 \\
\hline 20.70 & 1-Dodecanol & $\mathrm{C}_{12} \mathrm{H}_{26} \mathrm{O}$ & 186 & 29.59 & 91 \\
\hline 21.11 & 2-Tridecanone & $\mathrm{C}_{13} \mathrm{H}_{26} \mathrm{O}$ & 198 & 1.14 & 94 \\
\hline 21.38 & Germacrene D & $\mathrm{C}_{15} \mathrm{H}_{24}$ & 204 & 0.19 & 98 \\
\hline 21.46 & Alpha farnesene & $\mathrm{C}_{15} \mathrm{H}_{24}$ & 204 & 0.19 & 97 \\
\hline 21.88 & Azulene & $\mathrm{C}_{15} \mathrm{H}_{24}$ & 204 & 0.15 & 98 \\
\hline 21.98 & $\begin{array}{l}\text { Phenol, 2- } \\
\text { methoxy-4-(2- } \\
\text { propenyl)-, } \\
\text { acetate }\end{array}$ & $\mathrm{C}_{12} \mathrm{H}_{14} \mathrm{O}_{3}$ & 206 & 0.16 & 98 \\
\hline 22.10 & Naphthalene & $\mathrm{C}_{15} \mathrm{H}_{24}$ & 204 & 0.54 & 98 \\
\hline 22.94 & Dodecanoic acid & $\mathrm{C}_{12} \mathrm{H}_{24} \mathrm{O}_{2}$ & 200 & 8.4 & 99 \\
\hline 23.45 & Cyclododecene & $\mathrm{C}_{12} \mathrm{H}_{22}$ & 166 & 0.11 & 93 \\
\hline 23.72 & $\begin{array}{l}\text { Acetic acid, } \\
\text { dodecyl ester }\end{array}$ & $\mathrm{C}_{14} \mathrm{H}_{28} \mathrm{O}_{2}$ & 228 & 5.99 & 94 \\
\hline 23.91 & Hexadecanal & $\mathrm{C}_{16} \mathrm{H}_{32} \mathrm{O}$ & 240 & 1.33 & 95 \\
\hline 23.98 & $\begin{array}{l}\text { Caryophyllene } \\
\text { oxide }\end{array}$ & $\mathrm{C}_{15} \mathrm{H}_{24} \mathrm{O}$ & 220 & 0.58 & 94 \\
\hline 25.02 & $\begin{array}{l}\text { Cis-9-tetradecen- } \\
\text { 1-ol }\end{array}$ & $\mathrm{C}_{14} \mathrm{H}_{28} \mathrm{O}$ & 212 & 0.42 & 91 \\
\hline 25.13 & $\begin{array}{l}1,13- \\
\text { tetradecadiene }\end{array}$ & $\mathrm{C}_{14} \mathrm{H}_{26}$ & 194 & 1.59 & 91 \\
\hline 25.38 & Cyclododecane & $\mathrm{C}_{12} \mathrm{H}_{24}$ & 168 & 6.47 & 98 \\
\hline 25.53 & Ar-tumerone & $\mathrm{C}_{15} \mathrm{H}_{20} \mathrm{O}$ & 216 & 0.29 & 49 \\
\hline 25.85 & 2-Pentadecanone & $\mathrm{C}_{15} \mathrm{H}_{30} \mathrm{O}$ & 226 & 0.17 & 50 \\
\hline 26.00 & Patchouli alcohol & $\mathrm{C}_{15} \mathrm{H}_{26} \mathrm{O}$ & 222 & 0.53 & 99 \\
\hline 27.22 & $\begin{array}{l}\text { Tetradecanoic } \\
\text { acid }\end{array}$ & $\mathrm{C}_{14} \mathrm{H}_{28} \mathrm{O}_{2}$ & 228 & 1.11 & 99 \\
\hline 27.95 & $\begin{array}{l}\text { E-7-dodecen-1-ol } \\
\text { acetate }\end{array}$ & $\mathrm{C}_{16} \mathrm{H}_{30} \mathrm{O}_{2}$ & 254 & 0.21 & 91 \\
\hline 28.15 & Cyclotetradecane & $\mathrm{C}_{14} \mathrm{H}_{28}$ & 196 & 0.85 & 98 \\
\hline 29.72 & Cyclotetradecane & $\mathrm{C}_{14} \mathrm{H}_{28}$ & 196 & 0.16 & 95 \\
\hline
\end{tabular}

\subsection{Chemical Composition of the Essential Oil}

Bioactive compounds of E. elatior were identified through GC-MS analysis. Thirty-five compounds were 


\subsection{Antibacterial activity}

Essential oil of $E$. elatior was evaluated for antibacterial activity against $E$. coli, $P$. aeruginosa, $B$. cereus and $S$. aureus by observing clear inhibition zone of discs. All bacteria were successfully inhibited by essential oil at various concentrations as shown in Table 3 . The largest zone inhibitions were observed such as 41.67; $19.33 ; 14 ; 13.33 \mathrm{~mm}$ for $B$. cereus, $S$. aureus, $E$. coli and $P$. aeruginosa, respectively at $100 \%$ of concentration. At $20 \%$ of concentration, essential oil demonstrated the highest inhibition against $B$. cereus and $S$. aureus with zone of inhibition 25 and $15.2 \mathrm{~mm}$, respectively but showed no activity against $E$. coli and $P$. aeruginosa. The oil started to inhibit $B$. cereus with a moderate activity at lowest concentration and strongly inhibited at $100 \%$ of concentration.

Table 3. Disc diffusion result

\begin{tabular}{|c|c|c|c|c|}
\hline & \multicolumn{4}{|c|}{ Zone of inhibition (mm) } \\
\hline $\begin{array}{c}\text { Concentratio } \\
\text { ns (\%) }\end{array}$ & B. cereus & S. aureus & E.coli & $\begin{array}{c}\text { P. } \\
\text { aeruginosa }\end{array}$ \\
\hline $20 \%$ & $25 \pm 2.00$ & $15.2 \pm 0.80$ & - & - \\
\hline $40 \%$ & $30 \pm 3.00$ & $16.8 \pm 1.80$ & - & $12.33 \pm 0.58$ \\
\hline $60 \%$ & $34.33 \pm 6.80$ & $18.27 \pm 0.30$ & 11.67 & $13 \pm 0.00$ \\
& & & \pm 1.15 & \\
\hline $80 \%$ & $39.33 \pm 3.21$ & $18.57 \pm 1.10$ & $13.67 \pm$ & $13 \pm 0.00$ \\
& & & 1.53 & \\
\hline $100 \%$ & $41.67 \pm 6.03$ & $19.33 \pm 1.58$ & $14 \pm 1.00$ & $13.33 \pm 0.58$ \\
\hline
\end{tabular}

\section{Discussion}

Several researches about bioactivity of various parts of E. elatior such as fruit, leave and steam have been reported. Inhibitory activity of essential oil from E. elatior fruit increased as concentration of sample increased based on increasing of inhibition zone of treated discs [8]. Among of bacteria, B. cereus was the most sensitive to essential oil because it had the greatest inhibition zone at $20 \%$ of concentration. S. aureus was inhibited by the essential oil better than $E$. coli and $P$. aeruginosa. Gramnegative bacteria ( $E$. coli and $P$. aeruginosa) were sensitive to polar compounds because the cell walls of gram-negative bacteria had similar polarity which easier passed by. Meanwhile sensitivity of gram-positive bacteria to non-polar compounds occurred because of peptidoglycan which one of the constituent amino acid alanine is hydrophobic (nonpolar). Antimicrobial compounds could react with the phospholipid component of cell membranes causing lysis in cell [9]. Terpenoids are majority compounds in essential oil which commonly exhibit antibacterial activity. It can bind proteins and lipids in cell membranes which cause cell cell lysing [10]. Membranes contain of proteins and lipids that are highly susceptible to chemical substances which are able to lower the surface tension. Damage on cell membrane causes disruption of the nutrient transport (such as compounds and ions) through the cell membrane which impacted on nutrient deficiency of growth cell [11]. Alpha-pinene, patchouli alcohol, 1-dodecanol [12], Ar-tumeron and caryophyllene oxide [13], were predicted as terpenoids compounds in the essential oil which showed antibacterial activity against $S$. aureus, E. coli, B. subtilis and $P$. aeruginose.

Essential oils have been known to have antibacterial property due to phenolic compounds. Phenol compounds bind to the protein through hydrogen bonds, resulting on protein structures damage. Most of the structure of the cell wall and cytoplasmic membrane of bacteria contains proteins and fats. Instability in the cell wall and cytoplasmic membrane of bacteria causing the function on selective permeability, active transport, and control of protein composition of bacteria cells become impaired which will result in the losing of macromolecules and ions from the cell. This condition effects on loss of bacterial cell shape and lysing process [14].

\section{Conclusion}

This study revealed that E. elatior fruit produced a low yield of essential oil. The oil showed s strongly antibacterial activity which has potential as antibacterial agent. Further studies about isolation of bioactive compounds and mode of action on E. elatior should be conducted.

\section{Acknowledgements}

Thanks to the management and staff of Bogor-based Field Botany Research Center for Biology-LIPI Cibinong West Java has helped to identify plant specimens. Thanks also to the Head of the Laboratory of Integrated UIN Syarif Hidayatullah Jakarta, which has facilitated this research and Laboratory Research Institute for medicinal plants (Balitro) Cimanggis, Bogor which has helped distillation process of E. elatior fruit.

\section{References}

[1] Kobandaha, L., 2008, Bahan Pengawet dalam Produk Pangan, Rumah Sakit Awal Bross, Pekanbaru.

[ 2 ] Tranggono, Z.N., Wibowo D., Murdjiati G., and Mary A., 1990, Kimia Nutrisi Pangan, PAU Pangan dan Gizi UGM, Yogyakarta.

[ 3 ] Koswara, S., 2009. Pengawet Alami untuk Produk dan Bahan Pangan. eBookPangan.com.

[4] Thongson, C., Davidson, P.M., Mahakarnchanakul, W., and Weiss, J., 2004, Letters in Applied Microbiology. Vol 39, pp. 401-406.

[ 5 ] Hidayat S.S., and Hutapea J.R., 1991. Inventaris tanaman Obat Indonesia, Badan Penelitian dan Pengembangan Departemen Kesehatan Republik Indonesia.

[6] Mckeen, M.M., Ali, A.M., El-Sharkawy, S.H., Manap, M.Y., Salleh, K.M., Lajis, N.H., and Kamazu, K., 1997. Pharmaceumatical Biology, Vol 35, No 3, pp. 174-178.

[ 7 ] Jaafar F. M. , Osman, C. P., Nor, Hadiani Ismail and Khalijah Awang. 2007. Analysis of essential oils of leaves, stems, flowers and rhizomes of Etlingera Elatior (JACK) R. M. SMITH. The Malaysian Journal of Analytical Sciences, 11(1): pp. 269-273.

[ 8] Sugiastuti and Setyorini. 2002. Kajian Aktivitas Antibakteri dan Antioksidan Ekstrak Daun Sirih (Piper betle L.) pada Daging Sapi Giling. Program Pascasarjana, Institut Pertanian Bogor.

[ 9 ] Branen, A.L., and Davidson, P.J., 1993, Antimicrobials in Foods, Marcel Dekker, New York. 
[10 ] Nursal, S.W., and Juwita, W.S., 2006. Journal Biogenesis, Vol 2, No 2, pp. 64-66.

[11] Volk, W.A., and Wheeler. 1988. Mikrobiologi Dasar, Penerbit Erlangga, Jakarta.

[12 ] Pripdeevech, P., Saansoomchai, J. and Chiang Mai J. Sci. 2013. Vol 40, No 2, pp. 214-223.

[13 ] Kongkathip, N., Sam-ang, P., Kongkathip, B., 2009, Kasetsart Jornal of Natural Science, Vol 43, pp. 519 525 .
[14] Susanti, A. 2008, Jurnal universitas airlangga. Vol 1. No 1. 